＜第 46 回日本油化学会学会賞受賞論文 $>$

\title{
バイオミメティックアプローチによる活性酸素に関する研究
}

\section{Studies on Reactive Oxygen Species by Means of Biomimetic Approaches}

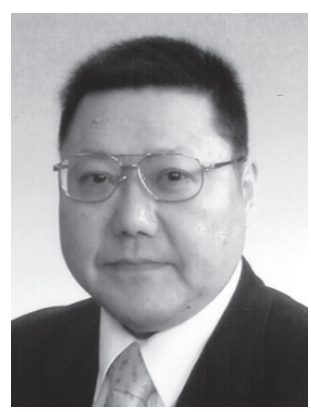

\author{
湯浅 真 1,2$)$ \\ 1) 東京理科大学理工学部工業化学科 \\ 2) 東京理科大学総合研究機構 \\ 干 278-8510 \\ 千葉県野田市山崎 2641 \\ Makoto YUASA ${ }^{1,2)}$ \\ Department of Pure and Applied Chemistry, \\ Faculty of Science and Technology, Tokyo \\ University of Science \\ 2) Research Institute for Science and \\ Technology, Tokyo University of Science \\ 2641 Yamazaki, Noda-shi, Chiba 278-8510, JAPAN
}

\begin{abstract}
論文要旨：バイオミメティックアプローチによる活性酸素に関する研究として，生体内での活性酸素検出 に関するセンサー研究ならびに生体内での活性酸素利用に関する抗酸化・抗癌剤研究ついて解説する。セン サー研究では, in situ にスーパーオキシドアニオンラジカルのような活性酸素を検出・定量できる電気化 学的なセンサーを創製し, 虚血再灌流モデル, 排卵モデル等の各種モデルにおいて活性酸素に基づく生体で の病理作用，生理作用等に関する知見を得ている。抗酸化・抗癌剂研究では，スーパーオキシドジスムター ゼミミックスに基づく抗酸化剤さらにはその作用による抗癌剤を創製し，高い抗癌作用を有するナノドラッ グデリバリーシステムを構築している。
\end{abstract}

\begin{abstract}
The author explains in detail for the sensor research detecting reactive oxygen species (ROS) in vivo and for the research of antioxidant and anticancer drug as the studies on ROS by means of biomimetic approaches. Firstly, in the sensor research, he creates the electrochemical sensor that it is possible to detect and determine the quantity of ROS such as superoxide anion radical $\left(\mathrm{O}_{2}{ }^{-}\right)$in situ . Then, he obtains the knowledge for pathology and physiological actions based on ROS in various model as ischemia-perfusion, ovulation, etc. Secondly, in the drug research, he creates the antioxidant and anticancer drug on the basis of superoxide dismutase (SOD) mimics. Then, he fabricates the nanodrug delivery system (n-DDS) having a potential to act as a carcinostatic agent.
\end{abstract}

Key words: Biomimetic approach, Reactive oxygen species (ROS), Superoxide anion radical $\left(\mathrm{O}_{2}^{-\cdot}\right)$, ROS sensor, Anticancer drug, Nano-drug delivery system (n-DDS)

\section{1 はじめに}

生体の多くは呼吸により酸素 $\left(\mathrm{O}_{2}\right)$ を取り入れ，そ れを細胞内に運んで有機物を酸化する際に発生するエネ ルギーを利用して生命を支えている。その過程でスー パーオキシドアニオンラジカル $\left(\mathrm{O}_{2}{ }^{-\cdot}\right)$ 等の活性酸素 [㛜 密には活性酸素種（Reactive Oxygen Species, ROS）で あるが，ここでは活性酸素と略称するが生成する。生 体において $\mathrm{O}_{2}{ }^{-\cdot}$ のような活性酸素は生命機構を支える

連絡者：湯浅 真

E-mail : yuasa@rs.noda.tus.ac.jp
不可欠な因子として機能しており，また，過剩な活性酸 素の生成に対してはスーパーオキシドジスムターゼ (SOD), グルタチオンペルオキシダーゼ, カタラーゼ 等のラジカル消去系酵素を備えることにより恒常的なバ ランスを保っている[生理作用（“作用”と略称する)］。 しかしながら, 生体内で活性酸素の生成と消去の恒常性 が崩れて酸化ストレス状態になると, 大量の活性酸素が 生成されて強いラジカル毒性が生じ, 引いては, 炎症疾 患, 神経疾患, 動脈硬化, 癌, 糖尿病, 虚血再灌流障害, 加歯促進等の多くの病態に陥ると考えられている[病理 作用（“障害”と略称する)］。このため, それら生理作 
用 (作用)，病理作用（障害）等の機序，制御，防止等 に関する広範な研究がなされている ${ }^{1-10)}$ 。特に, 脂質, 脂質関連の生体物質等に関する科学ならびに技術分野に おいても, 多数の活性酸素に関する研究が展開されてい る $^{2,4,5-10)}$ 。

著者は, 永年に亘り, 細胞 (脂質膜), ヘムタンパク質 等のバイオミメティックケミストリーを研究してきてい る。特異的な機能を有するへムタンパク質系の活性中心 であるへム（鉄（II）イオンを有する金属ポルフィリン）に 着目し，ポリペプチド等の役割を代替する修飾を施した金 属ポルフィリンをミミックすることにより，高性能な先端 材料の創製を展開している（Fig. 1)。例えば，Table $1^{6)} に$ 示すように, 赤血球ミミックスである人工酸素運搬体, シ トクロム $\mathrm{c}$ 酸化酵素系ミミックスである燃料電池触媒等の 高機能材料の創製を展開してきた ${ }^{6,11-20)}$ 。特に，このバ イオミメティックケミストリーによるアプローチに基づい た活性酸素に関する研究を精力的に推進している ${ }^{6-10)}$ 。こ こでは, 活性酸素の恒常性維持や非恒常性状態の早期発 見と活性酸素による癌細胞や組織への対処，消失等を目 指して，生体内における活性酸素検出としてのセンサー研

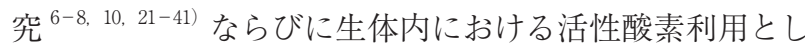
て SOD ミミックスのナノドラッグデリバリーシステム (n-DDS) による抗酸化・抗癌研究 $6,9,10,42-58)$ に（Table 1 の網掛け部分）ついて詳説する。

\section{2 活性酸素センサーに関する研究}

生体内においてin situで $\mathrm{O}_{2}{ }^{-\cdot}$ 等の活性酸素を検出, さらに定量できる電気化学的なセンサーをバイオミメ ティックアプローチにより創製した。具体的には, Fig. $2^{7}$, 8，10，21) に示すように，シトクロム $\mathrm{c}$ や SOD の活性 中心に対応する鉄ポルフィリンに導電性高分子の単量体 であるチオフェンの置換基を有するミミックスを新規に 分子設計ならびに合成し, その導電性重合膜を電極触媒 として用い, 活性酸素の酸化電流を計測することを原理 とする。本センサーは全合成かつ全固体型のセンサーで あり，生体用センサーとしてニードル型やカテーテル型

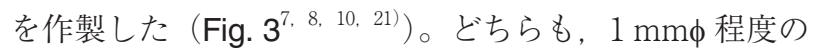
同軸上に中心より作用極／絶縁シールド／対極が設定さ れ，これのみで生体内での計測を可能にしている。

Fig. $4(\mathrm{a})^{7,21)}$ に本センサーの電極触媒である導電性

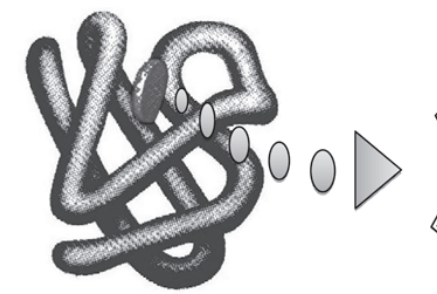

hemoprotein system

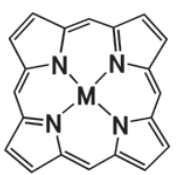

00

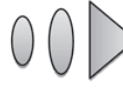

heme

(metalloporphyrin, $\mathrm{M}=\mathrm{Fe}(\mathrm{II})$ )

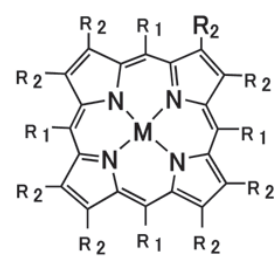

modified metalloporphyrin

Fig. 1 Biomimetic chemistry of hemoprotein systems.

Table 1 Functions of hemoprotein systems and these biomimetic chemistry ${ }^{6)}$.

\begin{tabular}{|c|c|c|}
\hline $\begin{array}{l}\text { hemoprotein } \\
\text { systems }\end{array}$ & functions (reactions) & biomimetic chemistry \\
\hline $\begin{array}{l}\text { Hemoglobin } \\
\text { Myoglobin }\end{array}$ & $\begin{array}{lr}\mathrm{O}_{2} \text { transport in blood } & \left([\mathrm{Fe}(\mathrm{II}) \mathrm{P}]_{4}+4 \mathrm{O}_{2} \rightleftarrows\left[\mathrm{Fe}(\mathrm{II}) \mathrm{P}-\mathrm{O}_{2}\right]_{4}\right) \\
\mathrm{O}_{2} \text { storage in muscle tissue } & \left(\mathrm{Fe}(\mathrm{II}) \mathrm{P}+\mathrm{O}_{2} \rightleftarrows \mathrm{Fe}(\text { II }) \mathrm{P}-\mathrm{O}_{2}\right)\end{array}$ & $\begin{array}{l}\text { artificial blood } \\
\qquad\left(\mathrm{O}_{2} \text { carrier }\right)\end{array}$ \\
\hline Cytochromes & $\begin{array}{l}\mathrm{e}^{-} \text {transfer in energy production system } \\
\qquad\left(\mathrm{Fe}(\mathrm{III}) \mathrm{P}+\mathrm{e}^{-} \rightleftarrows \mathrm{Fe} \text { (II) } \mathrm{P}\right)\end{array}$ & $\begin{array}{r}\text { reactive oxygen species } \\
\text { (ROS) sensor }\end{array}$ \\
\hline $\begin{array}{r}\text { Cytochrome } c \\
\text { oxidase }\end{array}$ & $\begin{array}{l}\mathrm{O}_{2} \text { reduction catalyst in energy production system } \\
\qquad\left(\mathrm{O}_{2}+4 \mathrm{e}^{-}+4 \mathrm{H}+\rightarrow 2 \mathrm{H}_{2} \mathrm{O}\right)\end{array}$ & $\begin{array}{l}\text { cathode catalyst of } \\
\text { fuel cell }\end{array}$ \\
\hline $\begin{array}{r}\text { Cytochrome } \\
\text { P-450 }\end{array}$ & $\begin{array}{l}\left.\mathrm{O}_{2} \text { (or } \mathrm{O}\right) \text { addition catalyst in metabolism system } \\
\qquad\left(\mathrm{S}+\mathrm{O}_{2}{ }^{*}+\mathrm{XH}_{2} \rightarrow \mathrm{SO} \mathrm{O}^{*}+\mathrm{X}+\mathrm{H}_{2} \mathrm{O}\right)\end{array}$ & catalyst of synthesis \\
\hline $\begin{array}{l}\text { Superoxide } \\
\text { dismutase }\end{array}$ & $\mathrm{O}_{2}^{-\cdot}$ dismutation catalyst in vivo & $\begin{array}{l}\text { anti-oxidant } \\
\text { anti-cancer drug }\end{array}$ \\
\hline $\begin{array}{l}\text { Peroxidase } \\
\text { Catalase }\end{array}$ & $\begin{array}{l}\text { use (reduction) of } \mathrm{H}_{2} \mathrm{O}_{2} \text { in vivo } \\
\text { decomposition of } \mathrm{H}_{2} \mathrm{O}_{2} \text { in vivo }\end{array}$ & $\begin{array}{l}\text { anti-oxidant } \\
\text { biosensing system }\end{array}$ \\
\hline Chlorophyll & $\begin{array}{l}\text { photosynthesis in plant } \\
\quad(\text { Photoenergy } \rightarrow \text { Chemical energy (Energy conversion) })\end{array}$ & $\begin{array}{l}\text { artificial phtosynthesis } \\
\left.\text { ( } \mathrm{H}_{2} \text { production }\right)\end{array}$ \\
\hline
\end{tabular}




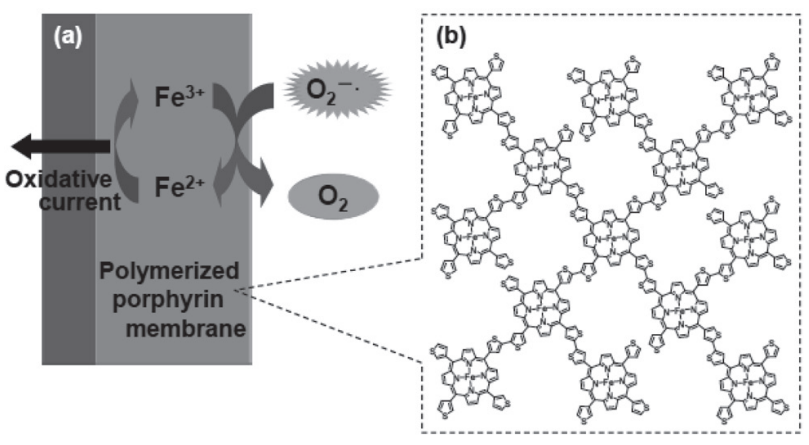

Fig. 2 (a) Mechanism for the amperometric response of the electropolymerized ironporphyrin-modified reactive oxygen species (ROS) sensor based on catalytic oxidation of ROS and (b) structure of electropolymerized ironporphyrin $7,8,10,21$.

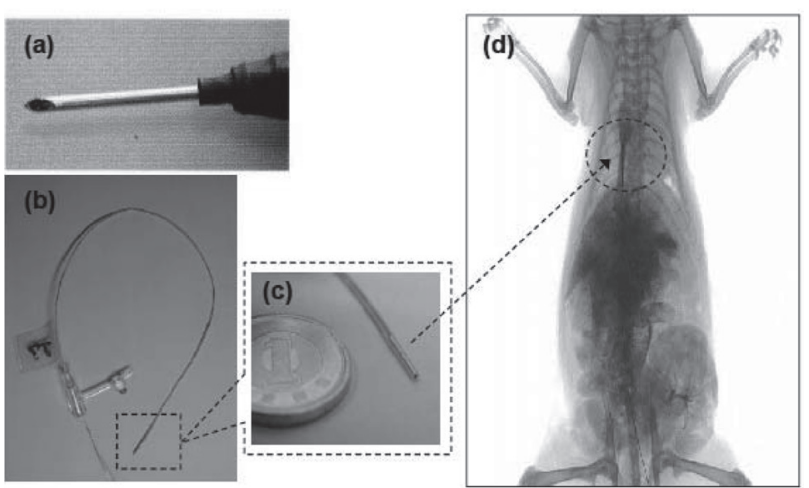

Fig. 3 Images of ROS sensors, (a) needle-typed sensor, (b) catheter-typed sensor and (c) expanded image of sensor head, and (d) X-ray photograph of rat inserting catheter-typed sensor in blood vessel ${ }^{7,}, 8,10$, 21).
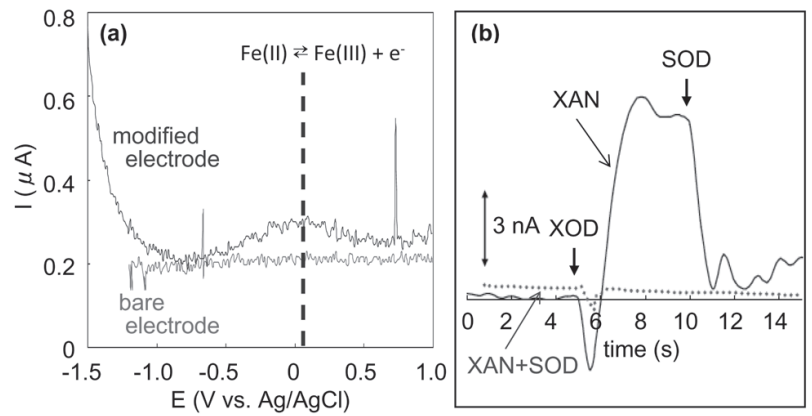

Fig. 4 (a) Differential pulse voltammograms (DPVs) at the electrode modified with electropolymerized ironporphyrin and bare electrode ${ }^{7,21}$. (b) Current response from the sensor modified with the electropolymerized ironporphyrin obtained for a solution of xanthine (XAN) in pH 7.4 phosphate buffer solution in the absence (solid curve) and the presence (dotted curve) of superoxide dismutase (SOD). "XOD" and "SOD" in this figure show the addition xanthine oxidase (XOD) and SOD to the solution, respectively $^{8,21)}$.
重合膜を修飾した炭素電極での微分パルスボルタモグラ ム（DPV）を示す。導電性重合膜を修飾していない裸 の炭素電極では観測されないピークが示され，これは電 極触媒である鉄ポルフィリンの鉄 $(I I ／ \mathbb{I I})$ に基づくレ ドックスピークであって, 鉄ポルフィリンが効果的に作 動している。さらに, Fig. 4 (b) ${ }^{8,21)}$ に示す本センサー の中和試験より，キサンチン $(\mathrm{XAN}) /$ キサンチンオキ シダーゼ（XOD）系による活性酸素の発生およびSOD による活性酸素の消失（中和）が確認できる。また, Fig. 5 7 ，8，10，21) に示すように, XAN/XOD 系の活性酸素 発生系において, XOD 添加濃度の増加に伴ってセンサー 電流值も増加しており, 定常状態でのセンサー電流増加 值 $(\Delta \mathrm{I})$ と XOD 添加濃度からの活性酸素濃度との相関 が得られている。これらより, 生体内での活性酸素の定 量的な検出を可能にしている。

また, 本センサーにおいて, 電極触媒である鉄ポルフィ リン, その導電性高分子となる単量体, 電解重合法等の 改良により, 高感度化, 高耐久性, 抗血栓性等の性能向 上を図り, 従来のバイオセンサー等に比べて多くの利点 を有するセンサーを構築している。例えば, 超臨界二酸 化炭素 $\left(\mathrm{scCO}_{2}\right)$ 溶媒中での電解重合により作製したセ ンサーによる高感度化の結果を Fig. $6^{41)}$ に示す。電極触 媒である導電性重合膜を $\mathrm{scCO}_{2}$ 溶媒中で合成したもの は, ジクロロエタンのような有機溶媒中で合成したもの に比べ, 拡散係数が大きく, 電荷移動速度が比較的遅い $\mathrm{ScCO}_{2}$ 環境によりゆっくりと高分子成長することで均一 かつ薄い膜が形成される (Fig. 6 (a))。このため, 導電 性, 触媒密度等が向上し, 高い電流応答に基づく高感度 化が達成できる。有機溶媒中で合成したものに比べ数 10 倍の電流応答, 低濃度検出が可能になる (Fig. 6 (b))。

本センサーは, 前述の Fig. 3 のようにニードル型やカ テーテル型に成形し, 生体内に留置した状態で継続的に 活性酸素を計測し, in vivoにおける各種虚血再かん流
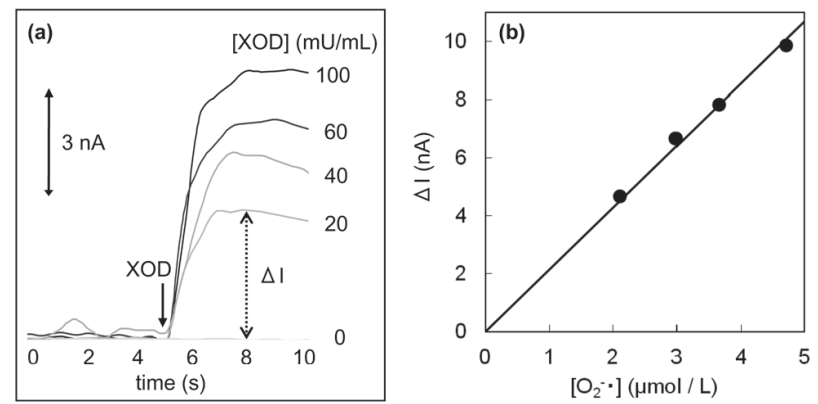

Fig. 5 (a) Current responses from ROS sensor obtained by the addition of various amounts of xanthine oxidase (XOD) to xanthine (XAN) solutions and (b) its working curve for ROS such as superoxide anion radical $\left(\mathrm{O}_{2}^{-\cdot}\right)$ detection ${ }^{7,8,10,21)}$. 


\section{(a) in $\mathrm{CH}_{2} \mathrm{Cl}_{2}$}
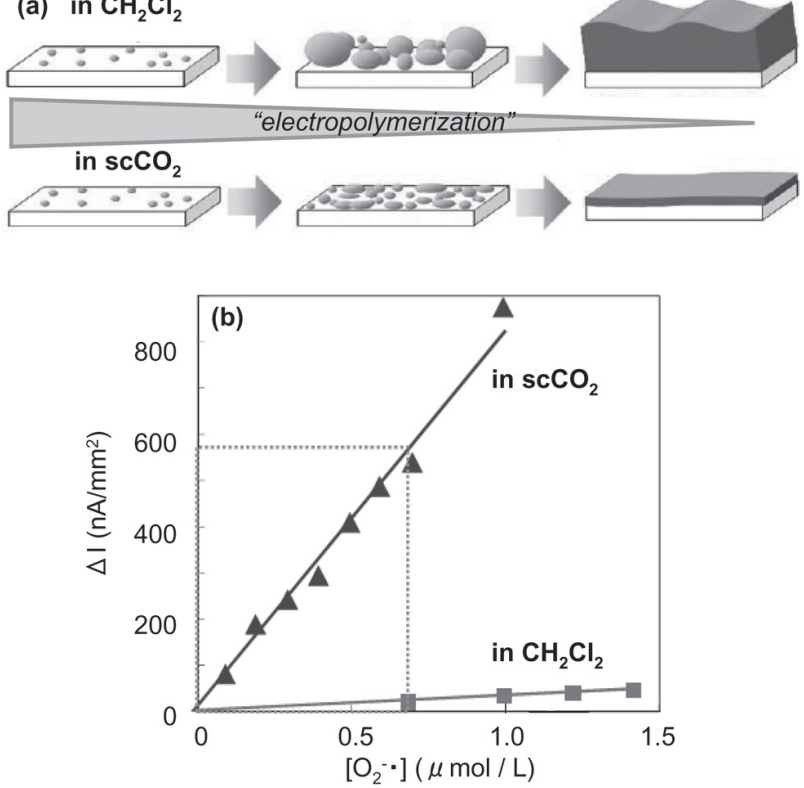

Fig. 6 (a) Growing process of the ironporphyrin films electopolymerized in organic solvent such as dichloroethane $\left(\mathrm{CH}_{2} \mathrm{Cl}_{2}\right)$ and in supercritical carbon dioxide $\left(\mathrm{scCO}_{2}\right)$ solvent. (b) working curves for ROS such as $\mathrm{O}_{2}^{-}$detection by using the electrodes modified with electropolymerized ironporphyrin in $\mathrm{CH}_{2} \mathrm{Cl}_{2}$ and in $\mathrm{ScCO}_{2}$ solvents ${ }^{41}$.

モデル，炎症モデル，排卵モデル等において，活性酸素 に基づく生体における病理作用，生理作用等に関係する 知見を明らかにしている。例えば，ヒトを含めた哺乳類 動物において排卵現象に活性酸素が関与していることが 示唆されている ${ }^{59,60)}$ 。ニードル型センサーを用いたウ サギ卵巣での in vivo 計測によりこの現象を評価してい る $\left(\right.$ Fig. $\left.7^{23)}\right)$ 。ウサギ卵巣としては, 卵胞の過剩発育を 促す馬絨毛性性腺刺激ホルモン（eCGあるいは妊馬血 清性性腺刺激ホルモン (PMSG) ) と排卵を促進する七 卜絨毛性性腺刺激ホルモン（hCG）を両投与した排卵誘

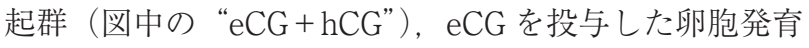
群（図中の “eCG”） およびホルモンを投与していない 未処置群（図中の “sham”）を検討し, eCG + hCG, eCG およびsham 群の確認を目視観察および酵素免疫測 定 (EIA) による血中ステロイド (エストラジオール $\left(\mathrm{E}_{2}\right)$ およびプロゲステロン $\left.\left(\mathrm{P}_{4}\right)\right)$ 濃度変化より行っている （Fig.9（a）および（b）。これらに基づき，各群につい てウサギ卵巣実質内にセンサーを穿刺してセンサーから の電流応答を計測している。定常状態での電流值（Fig. 7 (c)）の比較により, 排卵処置をした $\mathrm{eCG}+\mathrm{hCG}$ 群の ウサギ卵巣のみが他に比べて高い電流值を示している (Fig. 9 (d))。排卵中では活性酸素を産生する好中球や マクロファージが集積すること, 活性酸素の代謝・消去 系酵素であるSOD が局在すること等が報告されてお
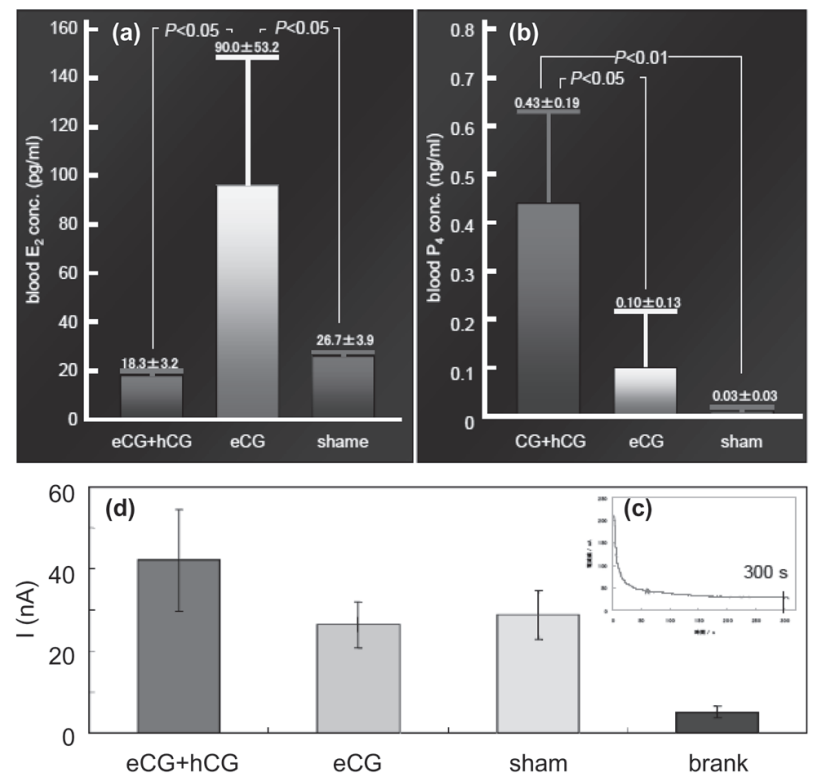

Fig. 7 in vivo detection of ROS such as $\mathrm{O}_{2}{ }^{-\cdot}$ in the area of the ovary at the time of ovulation of rabbit by using the needle-typed sensor. Blood-sex steroid concentrations such as (a) estradiol $\left(\mathrm{E}_{2}\right)$ and (b) progesterone $\left(\mathrm{P}_{4}\right)$ of the group administering equine chorionic gonadotropin (eCG) and human chorionic gonadotropin ( $\mathrm{eCG}+\mathrm{hCG}$ ), the group administering eCG (eCG) and the sham group. (c) Current response from ROS sensor and (d) the current values of the eCG +hCG, eCG and sham groups and blank $\mathrm{k}^{23)}$.

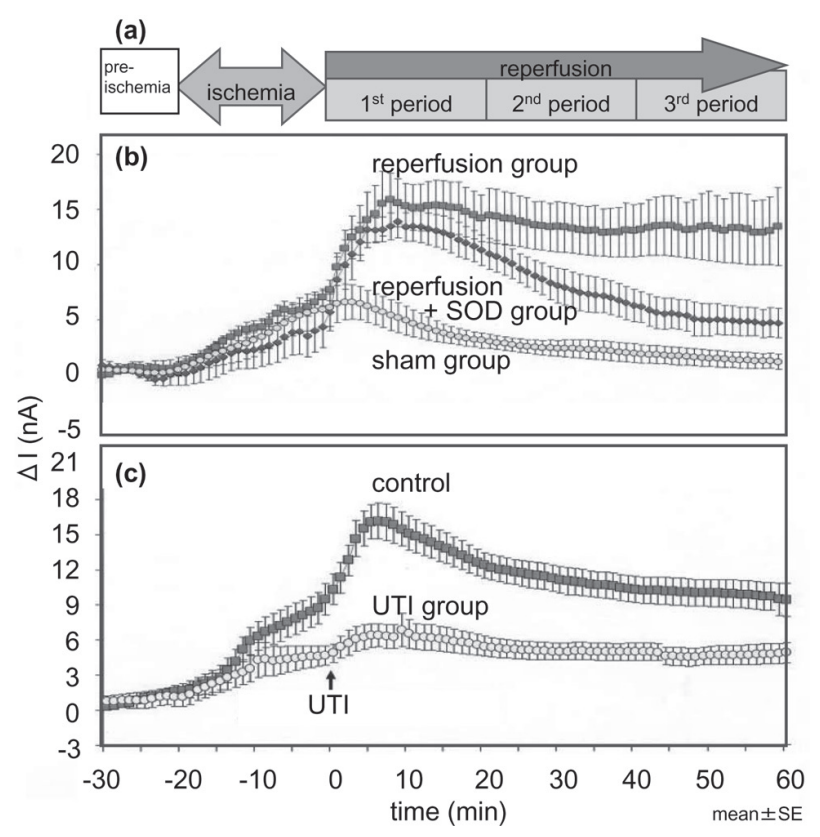

Fig. 8 in vivo detection of ROS such as $\mathrm{O}_{2}{ }^{-*}$ in the ischemia-reperfusion injury model of rat forebrain by using the catheter-typed sensor. (a) Comparison with the reperfusion group, the reperfusion and SOD addition group and the sham group. (b) Dosage effect of ulinastatin (UTI) ${ }^{31,39)}$. 

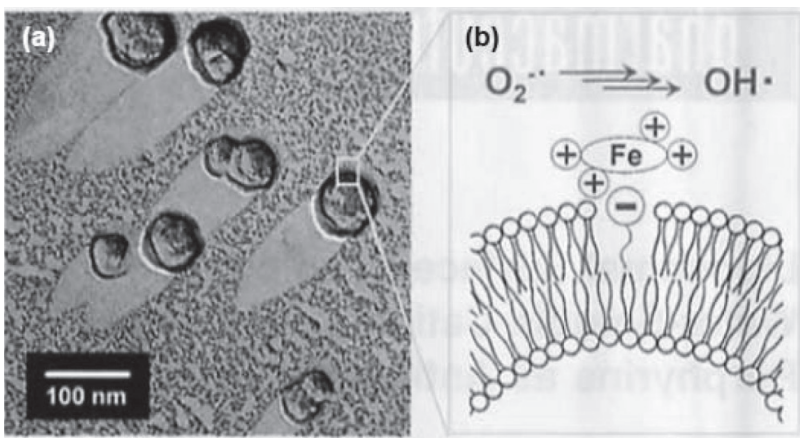

Fig. 9 (a) TEM image of ironporphyrin-loaded liposome as anticancer nano-drug delivery system (n-DDS) and (b) its structure and mechanism of anticancer action $^{9,45)}$.

$り^{59,60)}$, この高い電流值は活性酸素の発生によるもの と考えられる。このように、ニードル型センサーによる ウサギ卵巣での in vivo 計測により，排卵時の活性酸素 の関与を示唆する結果が得られている。

生体内において活性酸素が発生する事例として組織, 臓器等での虚血再灌流がある.カテーテル型センサーを 用いてラットの虚血再灌流における in vivo 計測を行い, 活性酸素発生を評価している ${ }^{30-41)}$ 。例えば, カテーテ ル型センサーをラット頸静脈内に留置し, 虚血時前より 電流值を経時的に計測している (Fig. 8 $\left.^{31,39)}\right)$ 。ラットに センサーを設置しただけの対照群（sham 群）では，ほ ぼ定常的な值を示すが, 虚血再灌流モデルのラット (reperfusion 群) においては, 再灌流後に電流值が増加 している。さらに, 虚血再灌流後にSOD を添加したラッ 卜 (reperfusion +SOD 群) においては，再灌流後に電 流值が増加し, SOD を添加すると電流值が減少してい る。これらより, 従来から指摘されていた虚血再灌流で の活性酸素・発生をin vivo かつ in situで計測, 確認し ている（Fig.8（b））。また，このような虚血再灌流障害 に臨床的な効果を発現するウリナスタチン(ウリナリー・ トリプシン・インヒビター（UTI））を虚血再灌流モデ ルに投与した場合においては, UTI 添加により虚血再 灌流障害が軽減されている（Fig. 8 (c))。このように, 診断, 治療等のモニターとして, 本センサーの可能性が 示唆されている。

\section{3 抗酸化剂・抗癌剤に関する研究}

生体内の過䛢な活性酸素の消去や代謝を促進する検討 の一つとして, SOD の作用 $((1) \sim(3)$ 式）を有するモ デル化合物（SOD ミミックス）が研究され，さらに， これを用いた生体内における活性酸素利用が推進されて いる。また，ナノオーダーのドラッグデリバリーシステ ムとして, 水溶性高分子, マイクロスフェア, 高分子ミ
セル，そして細胞ミミックスであるリポソーム等を用い たナノードラッグデリバリーシステム (n-DDS) 技術が 展開されている。ここで,生体用 n-DDSの要件としては, (1)腎排泄, 異物排除システム, 細網内皮系（Reticuloendothelial System, RES) 等の排泄 ·代謝回避性, (2)血中 安定性・滞留性, (3)患部組織・細胞集積性, (4)患部細胞内 輸送性，(5)患部 (組織・) 細胞選択攻撃性等がある ${ }^{9,61}$ 。

$$
\begin{aligned}
& \mathrm{SOD}\left[\mathrm{M}^{(\mathrm{n})+}\right]+\mathrm{O}_{2}^{-\cdot} \rightarrow \mathrm{SOD}\left[\mathrm{M}^{(\mathrm{n}-1)+}\right]+\mathrm{O}_{2} \\
& \mathrm{SOD}\left[\mathrm{M}^{(\mathrm{n}-1)+}\right]+\mathrm{O}_{2}^{-\cdot}+2 \mathrm{H}^{+} \rightarrow \mathrm{SOD}\left[\mathrm{M}^{(\mathrm{n})+}\right]+\mathrm{H}_{2} \mathrm{O}_{2}
\end{aligned}
$$

$$
\operatorname{SOD}\left[\mathrm{M}^{(\mathrm{n})+}\right]
$$

$2 \mathrm{O}_{2}{ }^{-\cdot}+2 \mathrm{H}^{+} \rightarrow \mathrm{O}_{2}+\mathrm{H}_{2} \mathrm{O}_{2}$

$\left[\mathrm{SOD}\left[\mathrm{M}^{(\mathrm{n})+}\right]\right.$ および $\mathrm{SOD}\left[\mathrm{M}^{(\mathrm{n}-1)+}\right]: \mathrm{SOD}$ の酸化状態 および還元状態, $\mathrm{H}^{+}$: 水素イオン, $\mathrm{H}_{2} \mathrm{O}_{2}$ : 過酸化 水素]

著者は, これらを融合し, 投与から癌細胞内作用まで を視野に入れて分子設計した，SOD および細胞ミミッ クスである修飾鉄ポルフィリンとリポソームから構成さ れる抗癌作用の n-DDSを検討している（鉄ポルフィリ ン導入リポソーム, Fig. 9 9, $\left.{ }^{45)}\right)$ 。この抗癌作用 n-DDSに は, Fig. 109) に示すように, 投与後の(1)および(2)を考慮 した粒径（4 nm〜400 nm 程度），ポリエチレングリコー ル (PEG) 表面修飾等が, (3)を考慮したEPR（Enhanced Permeability and Retention) 効果を発現させる粒径 (100 nm 以下), 光線力学療法 (Photo-dynamic Therapy）の裏付けによるポルフィリンのリガンド物質とし ての導入等が, (4)として細胞へのリポソームの吸着, 融 合, エンドサイトーシス等を考慮した $\mathrm{pH}$ 感受性, リガ ンド物質導入等の機能性リポソーム設計が, そして, (5) として癌細胞に選択的な DNA 阻害, 細胞膜損傷, 細胞 死等を誘導させる薬効として鉄ポルフィリンによる抗酸 化作用・Fenton 反応誘導のアポトーシス・ネクローシ ス作用等が施されている。

著者らが検討している SOD ミミックスである修飾へム タンパク質 ${ }^{43}{ }^{46,48)}$, 高分子結合金属ポルフィリン ${ }^{42,44)}$ 等の SOD 活性は, 分子設計において活性酸素導入のた めのカチオン性官能基を活性部位近傍に構築したもの で，その付近の高分子ドメインの立体障害により影響を 受ける。そこで, 高分子系であっても立体障害の影響を 受けないような分子設計が重要となり，デンドリマー型 


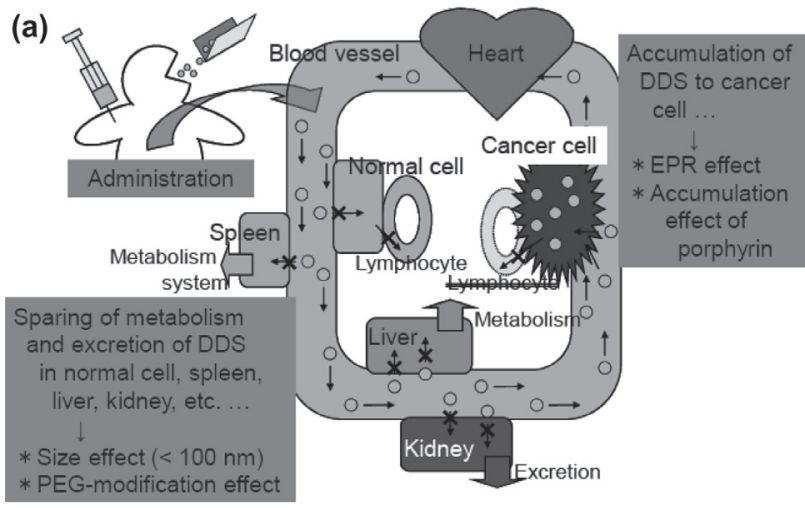

(b)

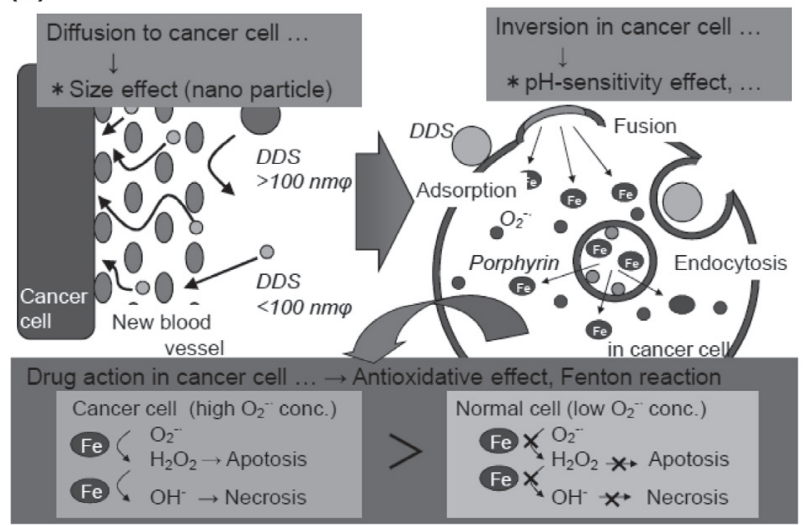

Fig. 10 Mechanisms for the n-DDS of anticancer drug and its factor on molecular design (a) in the prescription to cancer cell and (b) in cancer cell ${ }^{9)}$.

多量化金属ポルフィリンを ${ }^{50)}$, さらに, より高分子量で, かつ，活性部位である鉄やマンガン等の金属ポルフィリ ンを表面・表層に分子分散させる試みとして, リポソー ムの表層付近にカチオン性金属ポルフィリンを導入した 高分子系 SOD ミミックスである金属ポルフィリン導入 リポソームを得ている。これは, 水溶性であるカチオン 性金属ポルフィリンをリポソーム（小さな一枚膜ベシク ル，SUV）の表層に導入するために, カチオン性の金 属ポルフィリンとアニオン性の脂肪酸イオンからイオン コンプレックスを構築させたハイブリッドな分子集合体 構造である。特に，(aリポソームをSUVにしているの で粒径 $100 \mathrm{~nm}$ を切るサイズに調製できること（TEM 観察および動的光散乱測定より粒径 $30 \mathrm{~nm}$ 程度)，(bリ ポソームの成分組成が容易に変えられるので PEG，糖 鎖，リガンド等を導入でき，かつ，温度感受性， $\mathrm{pH}$ 感 受性等の機能を付与できること, ( 薬剤（活性部位）が イオンコンプレックスであるので容易に刺激に対して薬 剤徐放ができること，(d)ポソームなので二分子膜中に 疎水性㧍よび内水相に親水性の他の薬剂を封入できるこ と, (e金属ポルフィリンが表層付近に存在しているので これ自体がリガンド物質としても作用すること等であ
る。さらに,この金属ポルフィリン導入リポソームは, (f修飾へムタンパク質, 高分子結合金属ポルフィリン等 に比べ, 高いSOD 活性を示し, 高分子系でない低分子 系の SOD ミミックスと同等である $\left(k_{\text {cat }}\right.$ 值で $10^{7} \mathrm{M}^{-1} \mathrm{~S}^{-1}$ 程度 $\left.{ }^{9,45}\right)$ 。また，(g)金属ポルフィリンの親疎水バラン スを制御できるのでポルフィリン錯体の二分子膜中での 存在位置を変化させることが可能となり, SOD 活性を も調整することもできることも興味深い点である。

in vitroに打けるポルフィリン導入リポソームの細胞 内取り込みの確認をフローサイトメトリー（FCM）お よび共焦点レーザー走査顕微鏡観察（CLSM）から行っ ている(Fig. 11 抢よび $\left.12^{57)}\right)$ 。FCM での蛍光プローブ として, SOD ミミックスと同様な環構造を有する金属 フリーのカチオン性ポルフィリンを用いている。Fig. 11 に打いて，ポルフィリン導入リポソームを添加していな いコントロールに比ベ，ポルフィリン導入リポソームで は細胞当たりの蛍光強度の増大が観測され, 細胞へのポ ルフィリン導入リポソームの取り込みの可能性が示され ている。さらに, 同様の蛍光プローブを用いたCLSM(Fig. 12 (a)）から細胞内での蛍光が観測されている。また, 蛍光プローブとして Dextran-Texas Red ${ }^{\mathrm{TM}} を$ 用いた CLSM（Fig. 12 (b)）からは細胞へのポルフィリン導入

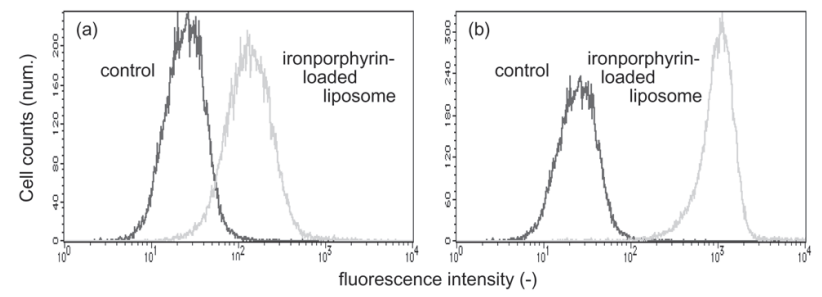

Fig. 11 Flow cytometry (FCM)-histograms (single linear region) of the porphyrin-loaded liposomes composed of (a) 5, 10, 15, 20-tetra (N-methylpyridinium-4-yl) porphyrin $\left(\mathrm{H}_{2} \mathrm{~T} 2 \mathrm{MePyP}\right)$ and (b) 5, 10, 15, 20-tetra（S,S-dimethysulfonium-4-yl） porphyrin $\left(\mathrm{H}_{2} \mathrm{~T} 4 \mathrm{Me} 2 \mathrm{SuP}\right)$ as fluorescence probes ${ }^{57}$.
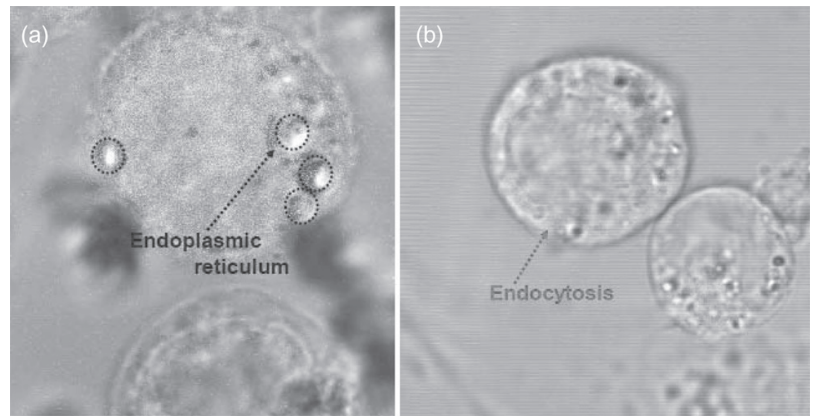

Fig. 12 Confocal laser scanning microscopy (CLSM) images of the porphyrin-loaded liposomes in cell by using the fluorescence probes as (a) metal-free porphyrin and Dextran-Texas Red ${ }^{\mathrm{TM}}$. 
リポソームの取り込みがエンドサイトーシスによる傾向 であることが示唆されている。

鉄ポルフィリン導入リポソームによる抗癌作用は, 癌 細胞中に高濃度存在する活性酸素である $\mathrm{O}_{2}{ }^{-\cdots}$ を抗酸化 剂であり，かつ, Fenton 試薬である鉄ポルフィリンを 有する本系が消去すると大量の過酸化水素 $\left(\mathrm{H}_{2} \mathrm{O}_{2}\right)$, ヒ ロキシラジカル $(\mathrm{OH} \cdot)$ 等が生成し，これらによりアポ トーシス，ネクローシス等が誘導され（抗酸化作用・ Fenton 反応誘導のアポトーシス・ネクローシス等), 癌 細胞をより優先的に死滅させるのである。例えば, Fig. 13 $3^{9,10,45)}$ にマウス肺癌細胞 Lewis Lung Caicinoma (LLC) を用いた Alamar Blue Assay に基づく殺細胞試験（in vitro 試験)の結果を示す。各抗癌剂での細胞生存率(LD) $50 \%$ における薬剤濃度 $\left(\mathrm{LD}_{50}\right)$ 值を比較したところ，シ スプラチン $5.0 \times 10^{-5} \mathrm{M}>$ マイトマイシン C (MMC) 2.6 $\times 10^{-5} \mathrm{M}>$ 金属ポルフィリン錯体導入 DMPC リポソー ム $1.3 \times 10^{-5} \mathrm{M}$ の順となり, 金属ポルフィリン錯体導入 リポソームは優れた抗癌作用を示している。さらに、リ ポソームを $\mathrm{pH}$ 感受性リポソームにしたところ,この $\mathrm{LD}_{50}$ 值は, $6.5 \times 10^{-6} \mathrm{M}$ となり, さらに抗癌作用が向上

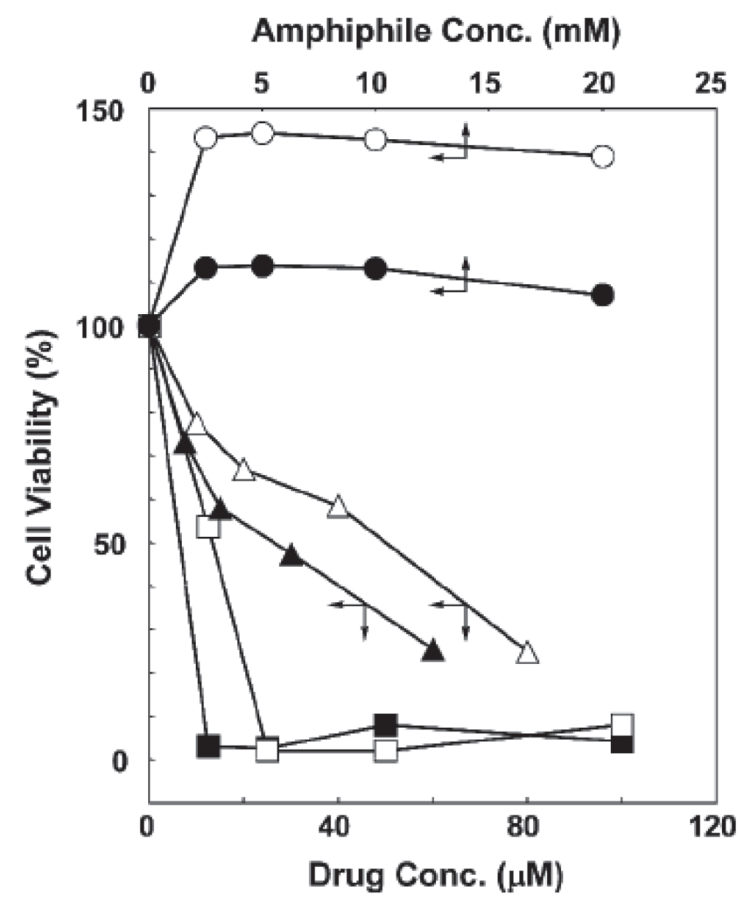

Fig. 13 Cell viability tests of Lewis lung carcinoma (LLC) tumor cells using alamar-blue assay for the liposomes in the absence $(\bigcirc)$ and the presence of ironporphyrin $(\square)$, the pH-sensitive liposomes in the absence ( and the presence of ironporphyrin $(\boldsymbol{\square})$, cisplatin $(\triangle)$, and mitomycine $\mathrm{c}(\boldsymbol{\Delta})$. The ironporphyrin concentration (in $\mu \mathrm{M}$ ) was determined from the amount of the amphiphile (in $\mathrm{mM}$ ), assuming that [ironporphyrin]/[amphiphile] $=1 / 200^{9}, 10,45$.
している。これより, 抗癌作用 n-DDSとしての優れた 効果が見出されている。

鉄ポルフィリン導入リポソームによる抗癌作用の in vivo 試験として, メラノーマ（皮膚癌）移植マウスに おける動物実験を行った。マウスのフットパットにメラ ノーマ(皮膚癌) 分散液を投与して癌を移植し, 移植後 $10 \mathrm{~d}$ において癌が定着しているのを確認している。尾 静脈より鉄ポルフィリン導入リポソーム等の抗癌剤を 0 ，4，8 および $12 \mathrm{~d}$ で 4 回投与し， $2 \mathrm{~d}$ 間隔で $20 \mathrm{~d}$ 程度 まで癌体積, 体重等の経過測定をしている。例えば, Fig. 14 に $20 \mathrm{~d}$ 後の目視観察を示す。抗癌剤を投与して いないマウス群（コントロール群）では，癌体積の大き な増大が観察される。また, 参照試料である市販品の抗 癌剤，シスプラチンを投与したマウス群（シスプラチン 投与群）では，コントロール群に比べて癌体積が減少し ている。鉄ポルフィリン導入リポソームを投与したマウ ス群（鉄ポルフィリン導入リポソーム投与群）では，コ ントロール群およびシスプラチン投与群に比べて，より 癌体積が減少し, 数例完全寛解しているもの（Fig. 14 (c) の左から 1 番目と 3 番目) も観察される。また, 別のマ ウスの動物試験において, 上記と同様な投与と経過測定 を行い, 経過日数〜相対癌体積増加率の関係をまとめた ものを Fig. 15 ${ }^{58)}$ に示す。コントロール群や参照試料で ある市販品の抗癌剤, マイトマイシン c を投与したマウ ス群（マイトマイシン c 投与群）では, 癌体積の増大が 見られる。鉄ポルフィリン, 鉄ポルフィリン導入 DPPC リポソーム, 鉄ポルフィリン導入 $\mathrm{pH}$ 感受性リポソーム 等を投与したマウス群では, 癌体積増大が抑制される傾 向を示している。鉄ポルフィリン導入 $\mathrm{pH}$ 感受性リポ
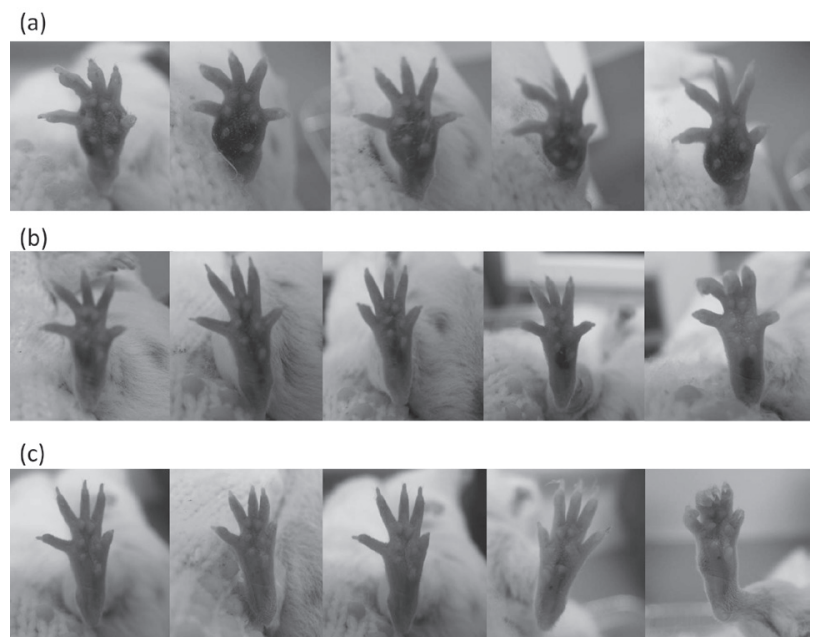

Fig. 14 Visual observations on the footpad of cancer transplantation-mice. (a) the control group, (b) the group administering cisplatin and (c) the group administering ironporphyrin-loaded liposome. 


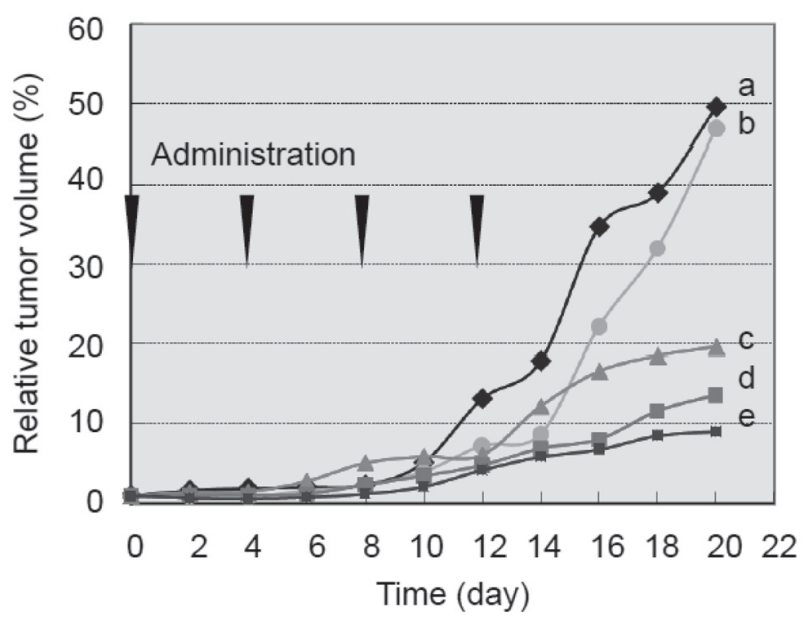

Fig. 15 Time dependence to relative tumor volume in treated mice with control (a), mitomycin C (b), ironporphyrin (c), ironporphyrin-loaded DPPC liposomes (d), and ironporphyrin-loaded pH-sensitive liposomes $(e)^{58)}$.

ソーム系では完全寛解するものも見られる。特に，鉄ポ ルフィリン系に比べて鉄ポルフィリン導入リポソーム系 では癌体積増加率が減少しておりn-DDSのため効果的 に薬剤が送達されていること, DPPCリポソーム系に比 ベて $\mathrm{pH}$ 感受性リポソームでは癌体積増加率がさらに減 少しておりエンドサイトーシス等によって薬剤が癌細胞 により効果的に取り込まれていること等が考察される。 in vivoにおいても, 抗癌作用 $\mathrm{n}$-DDS としての優れた効 果が見出されている。

\section{4 おわりに}

以上のように，活性酸素の恒常性維持や非恒常性状態 の早期発見と活性酸素による癌細胞や組織への対処, 消 失等を目指して，生体内における活性酸素検出としての センサー研究, 生体内における活性酸素利用として $\mathrm{SOD}$ ミミックスのナノドラッグデリバリーシステム (n-DDS) による抗酸化・抗癌研究等のバイオミメティッ クアプローチによる活性酸素に関する研究を解説した。 もしこれらの技術が可能になれば, 健康状態等をセン サーにより常に計測し, 抗酸化・抗癌作用のサプリメン トや薬剤等により健康維持等が可能となり, Fig. 16 に 示すような人間の健康管理, 食の安全管理等といった「豊 かな社会の実現」が可能になるでしょう。現在, 活性酸 素に関する研究・開発は, より広範な領域により多彩な 技術が拡がっている。これらの結実による先端技術の実 現,さらには, 豊かな社会の実現を切望する次第である。

最後に, 本研究の推進と展開ならびに本研究の貴学会 賞受賞に当たり，精神的な支えとなった家族，研究に協 力頂いた研究室のスタッフ, 学生, 修了・卒業された同

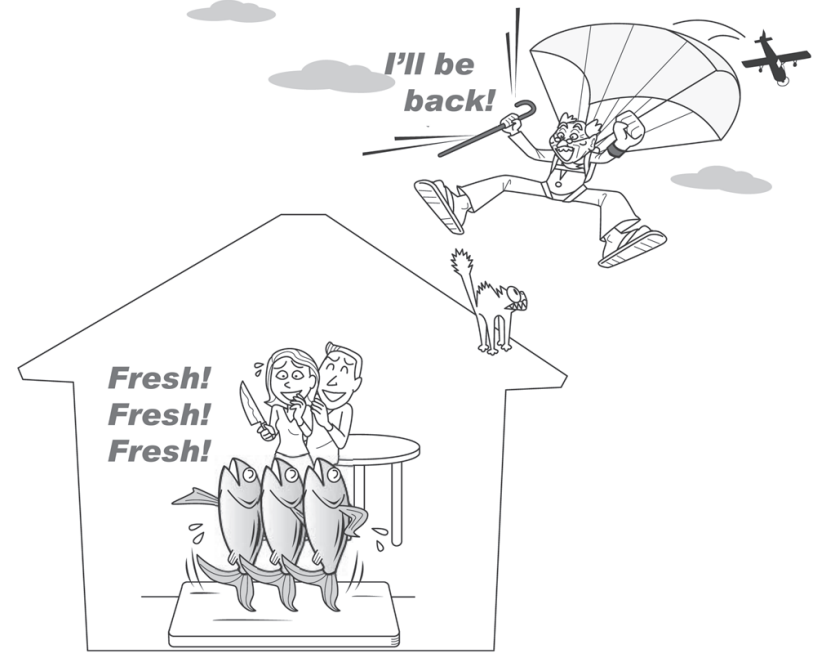

Fig. 16 The realization of generous human society by means of biomimetic approaches.

空の皆様ならびに貴学会の関係者の皆様に心より深くお 礼申し上げます。

\section{文 献}

1) J. M. McCord, I. Fridovich, J. Biol. Chem., 244, 6049 (1969).

2）中野稔, 浅田浩二, 大柳善彦, 活性酸素一生物での生成· 消去・作用の分子機構 - , 共立出版 (1988).

3) D. P. Riley, Chem. Rev., 99, 2573 (1999).

4）吉川敏一, 河野雅弘, 野原一子, 活性酸素・フリーラ ジカルのすべてー健康から環境污染までー, 丸善 (2000).

5）大柳善彦, 井上正康, 活性酸素と老化制御 - 多細胞社 会の崩壊と長寿へのシナリオー, 共立出版 (2001).

6）湯浅真，オレオサイエンス，1，131 (2001).

7) 湯浅真, 小柳津研一, 化学と教育, 53, 128 (2005).

8) M. Yuasa, K. Oyaizu, Curr. Org. Chem., 9, 1685(2005).

9）湯浅真, 小柳津研一, 村田英則, オレオサイエンス, 6, 307 (2006).

10）湯浅真，オレオサイエンス，11，45（2011）.

11）土田英俊, 湯浅真, 人工藏器, 14, 934 (1985).

12）湯浅真，土田英俊，高分子錯体アニュアルビュー, 11 (1986).

13) M. Yuasa, K. Aiba, Y. Ogata, H. Nishide, E. Tsuchida, Biochim. Biophys. Acta, 860, 558 (1986).

14) M. Yuasa, Y. Tani, H. Nishide, E. Tsuchida, J. Chem. Soc., Dalton Trans., 1917 (1987).

15) M. Yuasa, H. Nishide, E. Tsuchida, A. Yamagishi, J. Phys. Chem., 92, 2897 (1988).

16）湯浅真，表面，32，680（1994）.

17）湯浅真，表面技術，46，303（1995）.

18）湯浅真，表面，36，157（1998）.

19）湯浅真, 日本油化学会誌，49，315（2000）.

20）湯浅真, 小柳津研一, 村田英則, ケミカルエンジニア リング, 51, 353 (2006).

21) M. Yuasa, K. Oyaizu, A. Yamaguchi, M. Ishikawa, K. 
Eguchi, T. Kobayashi, Y. Toyoda, S. Tsutsui, Polym. Adv. Technol., 16, 287 (2005).

22) M. Yuasa, K. Oyaizu, A. Yamaguchi, M. Ishikawa, K. Eguchi, T. Kobayashi, Y. Toyoda, S. Tsutsui, Polym. Adv. Technol., 16, 616 (2005).

23）成相孝一, 石川満寿英, 江口勝哉, 坪田昭人, 藤瀬清隆, 小柳津研一, 湯浅真, 第 50 回日本不妊学会総会・学術 講演会抄録，No.O-05（2005，熊本）.

24）湯浅真, 小柳津研一, 村田英則, 石川満寿英, 筒井暁, 南波真広，高分子論文集，63，427（2006）。

25) M. Yuasa, K. Oyaizu, H. Murata, T. Kobayashi, T. Kobayashi, C. Kobayashi, J. Oleo Sci., 56, 81 (2007).

26）湯浅真, 小柳津研一, 村田英則, 江口勝哉, 豊田裕次郎, 高分子論文集，64，90（2007）.

27）湯浅真, 小柳津研一, 村田英則, 大関聖子, 青木徹也, Mater. Technol., 25, 175 (2007).

28）湯浅真, 小柳津研一, 村田英則, 豊田裕次郎, 南波真広, 設楽正樹，高分子論文集，65，349（2008）.

29）湯浅真, 小林朋広, 青木徹也, 藤井宏行, 五十嵐政嗣, 村田英則, Electrochemistry, 77, 940 (2009).

30) H. Shinagawa-Aki, M. Fujita, S. Yamashita, K. Fujimoto, K. Kumagai, R. Tsuruta, S. Kasaoka, T. Aoki, M. Nanba, H. Murata, M. Yuasa, I. Maruyama, T. Maekawa, Brain Res., 1292, 180 (2009).

31) M. Fujita, R. Tsuruta, S. Kasaoka, K. Fujimoto, R. Tanaka, Y. Oda, M. Nanba, M. Igarashi, M. Yuasa, T. Yoshikawa, T. Maekawa, Free Rad. Biol. Med., 47, 1039 (2009).

32) T. Ono, R. Tsuruta, M. Fujita, H. Shinagawa-Aki, S. Kutsuna, Y. Kawamura, J. Wakatsuki, T. Aoki, C. Kobayashi, S. Kasaoka, I. Maruyama, M. Yuasa, T. Maekawa, Brain Res., 1305, 158 (2009).

33) R. Tsuruta, M. Fujita, T. Ono, Y. Koda, Y. Koga, T. Yamamoto, M. Nanba, M. Shitara, S. Kasaoka, I. Maruyama, M. Yuasa, T. Maekawa, Brain Res., 1309, 155 (2010).

34) Y. Koda, R. Tsuruta, M. Fujita, T. Miyauchi, K. Kaneda, M. Todani, T. Aoki, M. Shitara, T. Izumi, S. Kasaoka, M. Yuasa, T. Maekawa, Brain Res., 1311, 197 (2010).

35) S. Kutsuna, R. Tsuruta, M. Fujita, M. Todani, T. Yagi, Y. Ogino, M. Igarashi, K. Takahashi, T. Izumi, S. Kasaoka, M. Yuasa, T. Maekawa, Brain Res., 1313, 242 (2010).

36) M. Todani, R. Tsuruta, M. Fujita, T. Nakahara, T. Yagi, C. Oshima, M. Igarashi, K. Takahashi, S. Kasaoka, M. Yuasa, T. Maekawa, Free Rad. Res., 44, 462 (2010)

37) R. Tanaka, M. Fujita, R. Tsuruta, K. Fujimoto, H. Shinagawa-Aki, K. Kumagai, T. Aoki, A. Kobayashi, T. Izumi, S. Kasaoka, M. Yuasa, T. Maekawa, Inflammation Res., 59, 597 (2010).

38) M. Fujita, R. Tsuruta, T. Kaneko, Y. Otsuka, S. Kutsu- na, T. Izumi, T. Aoki, M. Shitara, S. Kasaoka, I. Maruyama, M. Yuasa, T, Maekawa, Shock, 34, 299 (2010)

39) Y. Koga, R. Tsuruta, M. Fujita, Y. Koda, T. Nakahara, T. Yagi, T. Aoki, C. Kobayashi, S. Kasaoka, M. Yuasa, T. Maekawa, Neurological Res., 32, 925 (2010).

40) T. Kaneko, C. Kaise, Y. Kimoto, S. Suzuki, T. Kondo, M. Yuasa, J. Oleo Sci., 60, 647 (2011).

41）湯浅真他, 特許第 4128530 号, 特許第 4909632 号等.

42）湯浅真, 山口有朋, 大平俊明, 堀内愛子, 川上浩良, 朝山章一郎, 長岡昭二, Mater. Technol., 21, 7 (2003).

43) M. Yuasa, A. Yamaguchi, S. Mikami, U. Midorikawa, H. Kawakami, S. Nagaoka, J. Oleo Sci., 52, 149 (2003).

44) A. Yamaguchi, T. Ishino, N. Matsukura, H. Kawakami, S. Nagaoka, M. Yuasa, J. Oleo Sci., 52, 269 (2003).

45) M. Yuasa, K. Oyaizu, A. Horiuchi, A. Ogata, T. Hatsugai, A. Yamaguchi, H. Kawakami, Mol. Pharm., 1, 387 (2004).

46) M. Yuasa, K. Oyaizu, A. Yamaguchi, T. Hayashi, U. Midorikawa, J. Oleo Sci., 54, 115 (2005).

47) M. Yuasa, K. Oyaizu, A. Ogata, N. Matsukura, A. Yamaguchi, J. Oleo Sci., 54, 233 (2005).

48) M. Yuasa, K. Oyaizu, T. Hayashi, A. Yamaguchi, J. Oleo Sci., 54, 413 (2005).

49) M. Yuasa, K. Oyaizu, Y. Hanyu, K. Kasahara, A. Yamaguchi, J. Oleo Sci., 54, 465 (2005).

50) M. Yuasa, K. Oyaizu, Y. Hanyu, T. Hayashi, A. Yamaguchi, J. Oleo Sci., 54, 513 (2005).

51) H. Kawakami, K. Hiraka, M. Tamai, A. Horiuchi, A. Ogata, T. Hatsugai, A. Yamaguchi, K. Oyaizu, M. Yuasa, Polym. Adv. Technol., 18, 82 (2007).

52) M. Yuasa, K. Oyaizu, H. Murata, T. Hatsugai, A. Ogata, J. Oleo Sci., 56, 87 (2007).

53) M. Yuasa, K. Oyaizu, H. Murata, M. Komuro, J. Oleo Sci., 56, 95 (2007).

54）村田英則, 小柳津研一, 小室雅廉, 阿波亮太, 月岡東恵, 早乙女智洋, 湯浅真, 色材, 81，37 (2008).

55）村田英則, 伊藤裕二, 新保智幸, 小柳津研一, 湯浅真, 高分子論文集，65，277（2008）.

56) K. Hiraka, M. Kanehisa, M. Tamai, S. Asayama, S. Nagaoka, K. Oyaizu, M. Yuasa, H. Kawakami, Colloids \& Surf. B: Biointerfaces, 67, 54 (2008).

57）湯浅真, 佐原義純, 結城りさ, 立石哲也, 村田英則, 原泰志，小島周二，高分子論文集，67，82（2010）.

58）湯浅真他, 特許第 4741205 号等.

59) T. Suzuki, N. Sugino, T. Fukaya, S. Sugiyama, T. Uda, R. Takaya, A. Yajima, H. Sasano, Fertility and Sterility, 72, 720 (1999).

60）楢原久司，日本産科婦人科学会雑誌，52（11） N-403 (2000).

61）永井恒司監修, 新・ドラックデリバリーシステム, シー エムシー (2000). 